\title{
Virus
}

Research

\section{Evidence for the assignment of two strains of SPLV to the genus Potyvirus based on coat protein and $3^{\prime}$ non-coding region sequence data}

\author{
D. Colinet *, J. Kummert, P. Lepoivre \\ Faculté Universitaire des Sciences Agronomiques, Unité de Phytopathologie, 13 Avenue Maréchal Juin, B-5030 Gembloux, Belgium
}

Received 20 December 1996; received in revised form 30 January 1997; accepted 30 January 1997

\begin{abstract}
The use of potyvirus-specific primers and subsequent application of the RACE procedure allowed the cloning of the $3^{\prime}$ terminal 1088 nucleotides of the genomic RNA of the Taiwan isolate of sweetpotato latent virus (SPLV-T) and the $3^{\prime}$ genomic 1085 nucleotides of a SPLV-like virus from China (SPLV-CH). The sequence of an internal part of the presumptive nuclear inclusion $b$ gene was also determined for both isolates. Detailed sequence analyses revealed the presence of consensus motifs which indicated that SPLV-CH and SPLV-T should be regarded as members of the genus Potyvirus. Multiple sequence alignments and phylogenetic analyses were also performed and unambiguously assessed these isolates as strains of a distinct Potyvirus. SPLV was not related to other potyviruses infecting sweetpotato nor to any other sequenced virus. From the presence of the DAG box, SPLV-CH is expected to be a typical aphid transmitted Potyvirus whereas a conceivable explanation is proposed for the non-aphid transmission of SPLV-T. (C) 1997 Elsevier Science B.V.
\end{abstract}

Keywords: Potyvirus-specific primers; Coat protein; 3' non-coding region

\section{Introduction}

Sweetpotato is susceptible to infection by at least four members of the family Potyviridae (Clark and Moyer, 1988; Moyer and Salazar, 1989). In a previous study, three distinct po-

\footnotetext{
* Corresponding author. Tel.: + 3281622431 ; fax: + 3281 610126; e-mail: dcolinet@fsagx.ac.be
}

tyviruses were identified in a sweetpotato clone originating from China using the polymerase chain reaction (Colinet et al., 1994a). Preliminary results indicated that one of these viruses was closely related to a sweetpotato latent virus isolate from Taiwan (SPLV-T). Neither aphids nor whiteflies have been shown to transmit SPLV-T though it has some properties in common with potyviruses. The virus is a flexuous rod, approxi- 
mately 700-750 nm long and induces typical cylindrical inclusion proteins in the cytoplasm of infected cells (Clark and Moyer, 1988; Moyer and Salazar, 1989). Since SPLV-T was serologically related to potyviruses (Hammond et al., 1992), it was assigned as a possible member of the genus Potyvirus pending sequence information.

The taxonomy of the family Potyviridae has long been unsatisfactory largely due to complex biological and serological relationships between its members (Shukla et al., 1992, 1994; Ward and Shukla, 1991). A growing number of coat protein and genome sequence data of members of the family Potyviridae are becoming available. It has become clear that these data can be used for a more reliable taxonomy of these viruses than that based on either biological properties such as host range or symptomatology, or serological relationships. The recent increase in sequence data supported the establishment of the family Potyviridae and defined three genera correlated with transmission mode (Barnett et al., 1995; Shukla and Ward, 1989; Shukla et al., 1994; Ward et al., 1992). Among these, the genus Potyvirus, whose members are non-persistently transmitted by many aphid species, is the largest one with over 180 members (Barnett et al., 1995; Brunt, 1992). Comparison of coat protein core sequences clearly demonstrated a bimodal distribution of sequence identity among potyviruses and their strains, with the exception of some viruses which, though distinct, are more closely related to each other than to any other potyvirus (Shukla et al., 1994).

In order to clarify the genus status of SPLV and to further examine the relationship between SPLV-T and the SPLV-like virus from China (SPLV-CH), we determined the nucleotide sequence of the $3^{\prime}$ terminal part of the genomic RNAs of both viruses. These nucleotide sequences as well as the deduced amino acid sequences of the coat proteins have been compared to each other and to those of two potyviruses infecting sweetpotato, sweetpotato feathery mottle virus (SPFMV; Abad et al., 1992; Colinet and Kummert, 1993) and sweetpotato virus G (SPVG; Colinet et al., 1994b), and other potyviruses.

\section{Material and methods}

\subsection{Virus isolates, plant materials and RNA extraction}

Sweetpotato clone GN1 (Ipomoea batatas L.) originated from China, Guangdong province (Dr Feng Zu Xia, Upland Crops Research Institute, Guangzhou) and was maintained in Gembloux under greenhouse conditions. SPLV-T was received from Dr Brunt (AFRC Institute of Horticultural Research, Littlehampton, England) and propagated by mechanical transmission in Ipomoea nil and Nicotiana benthamiana. Total RNA was extracted from leaves with obvious signs of disease by the method of Chirgwin et al. (1979). Briefly, samples were ground in liquid nitrogen and homogenized in a guanidium thiocyanate solution. The RNA was then pelleted through a cesium chloride gradient.

\subsection{PCR amplification with potyvirus-specific primers}

Degenerate primers Pot1 (GACTGGATCCATTBTCDATRCACCA) and Pot2 (GACGAATTCTGYGAYGCBGATGGYTC) were previously designed to amplify the variable $5^{\prime}$ terminal part of the coat protein gene, together with the $3^{\prime}$ terminal part of the nuclear inclusion $b$ (NIb) gene of potyviruses (Colinet and Kummert, 1993). Oligo(dT) primed single stranded cDNA was synthesized from $5 \mu \mathrm{g}$ of total RNA using the Amersham cDNA synthesis kit. Five microliters from ten-fold dilutions in sterile water were used for the PCR experiments with the potyvirus-specific primers Pot1 and Pot2 (Colinet and Kummert, 1993). Amplification was performed in a volume of $100 \mu \mathrm{l}$ of PCR buffer $(10 \mathrm{mM}$ Tris $-\mathrm{HCl} \mathrm{pH}$ 9.5, $2.5 \mathrm{mM} \mathrm{MgCl}_{2}, 50 \mathrm{mM} \mathrm{KCl}, 0.1 \%$ Triton $\mathrm{X}-100)$ containing $200 \mu \mathrm{M}$ each of dATP, dCTP, dGTP and dTTP, $0.1 \mathrm{nM}$ each of upstream and downstream primers and 5 U Taq DNA polymerase (Promega). The following thermal cycling scheme was used for 37 reaction cycles (Biometra cycler): template denaturation at $94^{\circ} \mathrm{C}$ for $30 \mathrm{~s}$, primer annealing at $40^{\circ} \mathrm{C}$ (cycles 1-5) or $50^{\circ} \mathrm{C}$ (cycles 6-37) for $1 \mathrm{~min}$ and DNA 


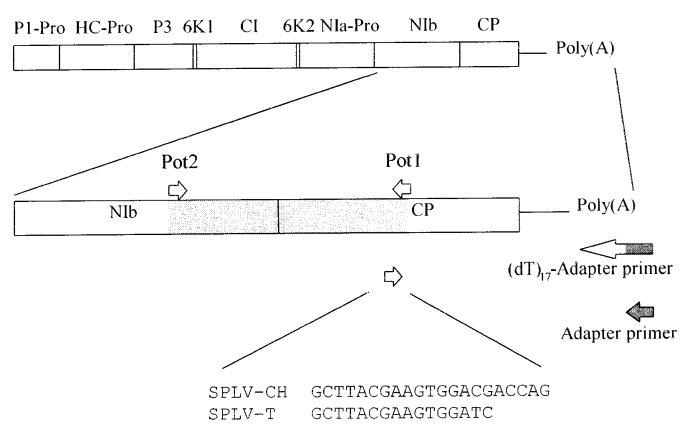

Fig. 1. Genetic map of the potyvirus genome showing the relative position of potyvirus-specific primers Pot1 and Pot2 (Colinet and Kummert, 1993) and RACE (Frohman, 1990) $(\mathrm{dT})_{17}$-Adapter and Adapter primers. Position and sequence of the specific primers designed from the known sequence of the $5^{\prime}$ terminal part of the coat protein gene of SPLV-CH and -T are also shown. The primers correspond to nucleotides 370390 and $373-388$ of the sequence of SPLV-CH and $-\mathrm{T}$, respectively. The hatched box represents the part of the genome amplified by RT-PCR with degenerate primers Pot1 and Pot2. P1-Pro, first protein/protease; HC-Pro, helper component/protease; $\mathrm{P} 3$, third protein; $6 \mathrm{~K} 1,6 \mathrm{~K}$ peptide; $\mathrm{CI}$, cytoplasmic inclusion protein; $6 \mathrm{~K} 2$, second $6 \mathrm{~K}$ peptide; NIa-Pro, nuclear inclusion a protein/protease; NIb, nuclear inclusion $b$ protein (RNA polymerase); $\mathrm{CP}$, coat protein.

synthesis at $72^{\circ} \mathrm{C}$ for $2 \mathrm{~min}$. After electrophoresis in a $1 \%$ agarose gel, the amplified DNA fragments were excised and eluted with the QIAEX Gel Extraction Kit from QIAGEN. Following digestion with Bam HI and Eco RI, the PCR products were directionally cloned in the Bluescript plasmid.

\subsection{Amplification of $c D N A 3^{\prime}$ ends}

The rapid amplification of cDNA ends (RACE) method (Frohman, 1990) was used to clone a cDNA fragment corresponding to the $3^{\prime}$ terminal region of the genome of SPLV-CH and -T. Single stranded cDNAs were synthesized using hybrid $\mathrm{dT}_{17}$-adapter primer GACTCGAGTCGACAGCGATTTTTTTTTTTTTTTTT (Frohman, 1990) instead of oligo(dT) primer, using the Gibco BRL Superscript Preamplification System. Amplifications were performed using adapter primer GACTCGAGTCGACAGCG (Frohman, 1990) and specific primers (Fig. 1) designed from the sequence determined for SPLV-CH and - T from the fragments amplified with the potyvirus-specific primers. After denaturation at $94^{\circ} \mathrm{C}$ for $5 \mathrm{~min}$, annealing at $50^{\circ} \mathrm{C}$ for $5 \mathrm{~min}$ and elongation at $72^{\circ} \mathrm{C}$ for $40 \mathrm{~min}$, the following thermal cycling scheme was used for SPLV-CH for 40 reaction cycles (Biometra cycler): template denaturation at $94^{\circ} \mathrm{C}$ for $30 \mathrm{~s}$, primer annealing at $50^{\circ} \mathrm{C}$ for $1 \mathrm{~min}$ and DNA synthesis at $72^{\circ} \mathrm{C}$ for $3 \mathrm{~min}$. A final 15 min elongation step at $72^{\circ} \mathrm{C}$ was performed at the end of the 40 cycles. Twenty-five more cycles were then performed on $1 \mu 1$ of a ten-fold dilution of the first amplification product. For SPLV-T the following thermal cycling scheme was used for 40 reaction cycles (Biometra cycler): template denaturation at $94^{\circ} \mathrm{C}$ for $40 \mathrm{~s}$, primer annealing at $50^{\circ} \mathrm{C}$ for $1 \mathrm{~min}$ and DNA synthesis at $72^{\circ} \mathrm{C}$ for $1 \mathrm{~min}$ $30 \mathrm{~s}$.

The SPLV-CH PCR product was cloned using pCR-Script $\mathrm{SK}(+)$ Cloning Kit (Stratagene)

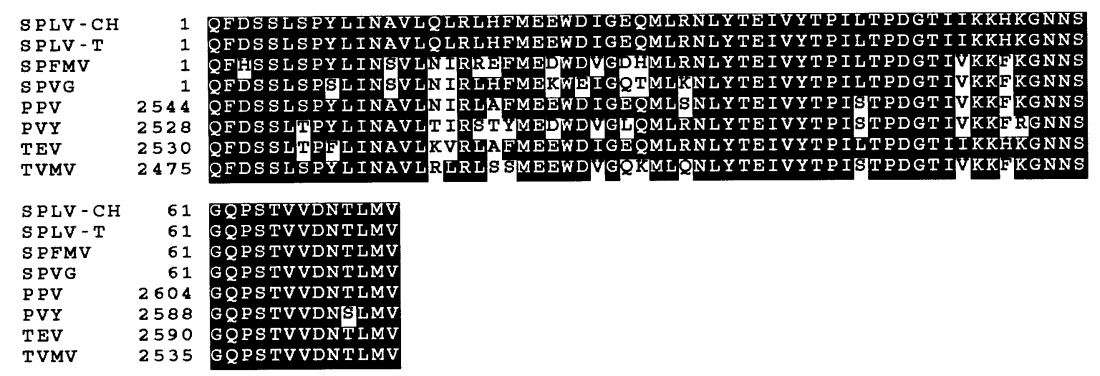

Fig. 2. Alignment of part of the C-terminal region of the NIb of SPLV-CH and -T and those of SPFMV, SPVG, PPV (from aa 2544 to 2615), PVY (from aa 2528 to 2600), TEV (from aa 2530 to 2602) and TVMV (from aa 2475 to 2547 ). 


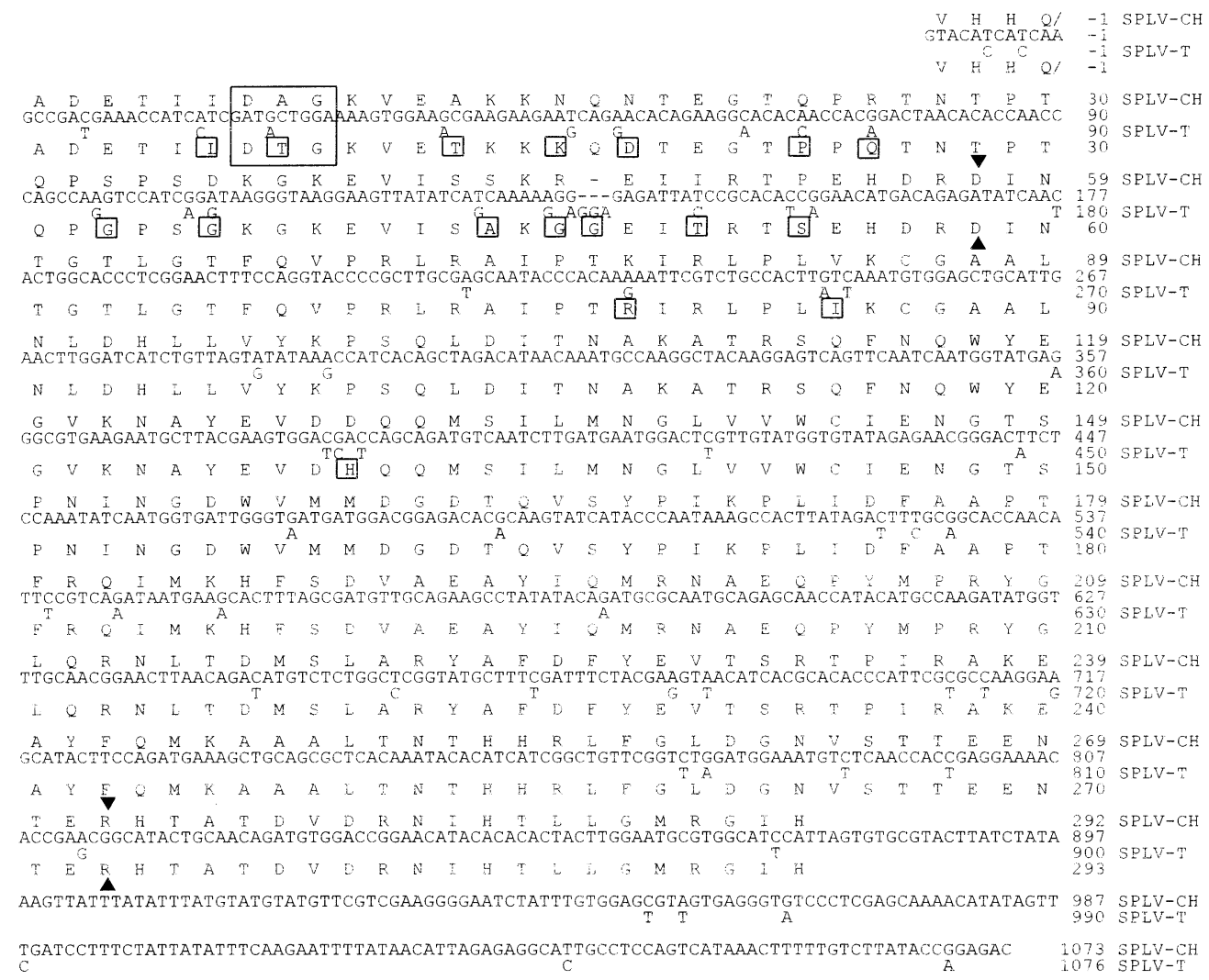

Fig. 3. Sequences of the SPLV-CH and SPLV-T coat protein gene and $3^{\prime}$ untranslated region. The complete nucleotide sequence of SPLV-CH is shown. Nucleotides of the SPLV-T sequence that differ from SPLV-CH are shown below the SPLV-CH sequence. The predicted amino acid sequences of the coat protein of SPLV-CH and SPLV-T are presented above and below the corresponding nucleotide sequence, respectively. Amino acids of the SPLV-T sequence that differ from SPLV-CH are boxed. The DAG motif is boxed; /, indicates the putative cleavage site between the NIb and the CP; $\mathbf{\nabla}$, indicates the first and the last amino acid of the potyvirus coat protein conserved core (equivalent to $\mathrm{D}^{33}$ to $\mathrm{R}^{248}$ in PVY). EMBL accession no. X84011 for SPLV-CH and no. X84012 for SPLV-T.

whereas the SPLV-T amplified fragment was cloned in the $\mathrm{pCR}^{\mathrm{TM}} \mathrm{II}$ plasmid (TA Cloning Kit from InVitroGen).

\subsection{Sequence analysis of the amplified fragments}

Because of the low fidelity of Taq DNA polymerase, which may lead to misincorporations, the sequence of the PCR products were deduced from three independent clones. Complete nucleotide sequence was obtained either by subcloning the amplified fragments after cleavage with restriction enzymes or by using specific primers derived from the sequences. Double-stranded DNA sequencing by the dideoxy chain termination method was performed using the T7 DNA polymerase (Pharmacia) according to manufacturer's instructions. Sequence analyses employed DNASIS and University of Wisconsin Genetics Computer Group (GCG) sequence analysis software package version 8.0 (Devereux et al., 1984). Sequence comparisons were performed with Genbank and EMBL databases. Multiple sequence alignments and dendrograms of sequence relationships were produced using CLUSTALV (Higgins et al., 1991). The following potyviruses were used for sequence alignments: SPFMV (Abad et al., 1992; Colinet and Kummert, 1993), SPVG (Colinet et 


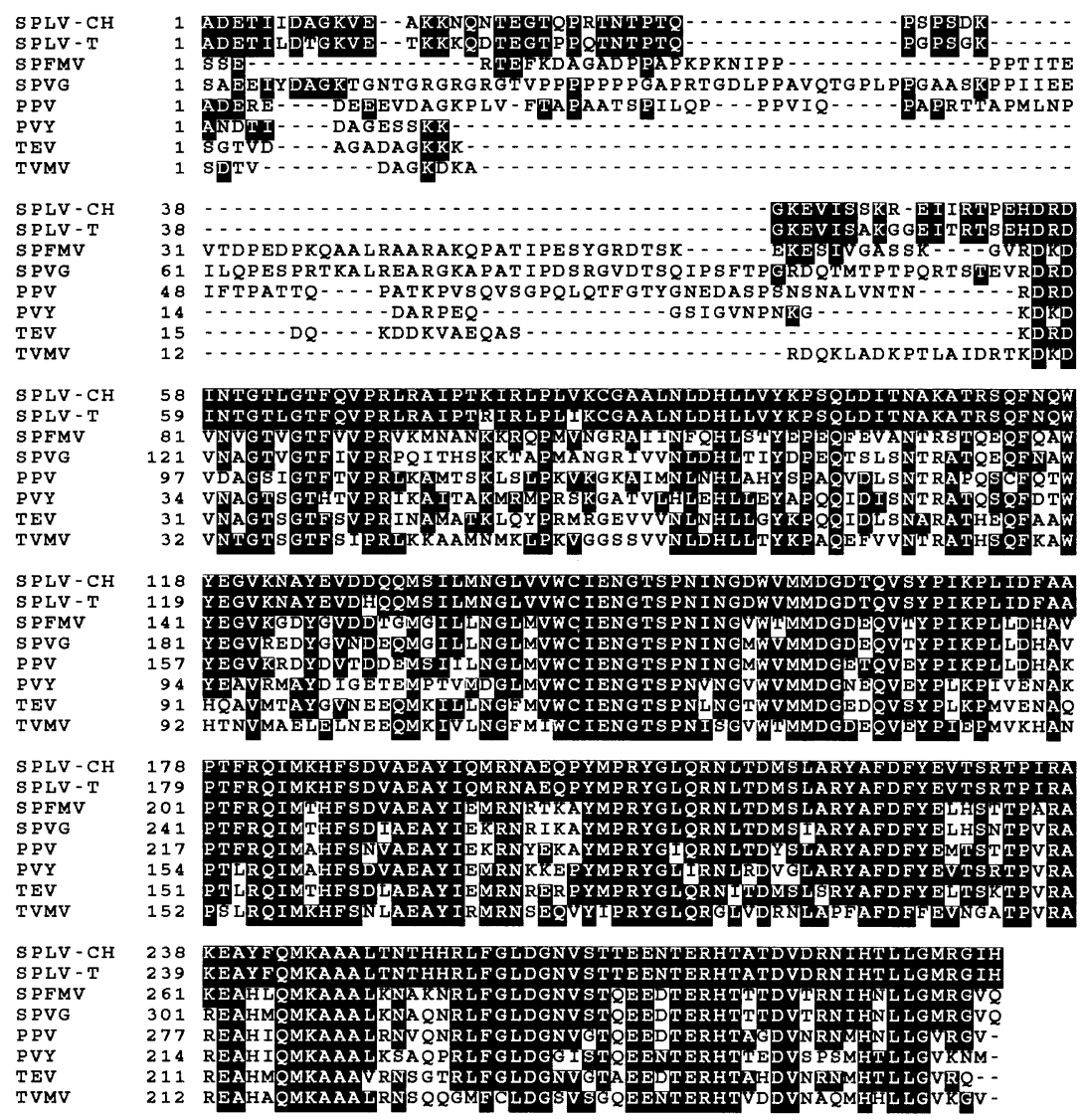

Fig. 4. Alignment of the coat protein amino acid sequences of SPLV-CH and -T and those of SPFMV, SPVG, PPV, PVY, TEV and TVMV. Identical amino acids are shaded. Sequences were aligned using ClustalV.

al., 1994b), plum pox virus (PPV; Lain et al., 1989), potato virus Y (PVY; Robaglia et al., 1989), tobacco etch virus (TEV; Allison et al., 1986) and tobacco vein mottling virus (TVMV; Domier et al., 1986).

\section{Results}

\subsection{Amplification of the $3^{\prime}$ terminal region of $S P L V-C H$ and $-T$ genome}

Potyvirus-specific PCR using degenerate primers Pot1 and Pot2 (Colinet and Kummert, 1993) was performed on total RNA isolated from SPLV-CH infected sweetpotato clone GN1 and from SPLV-T infected $N$. benthamiana. A 1.30 $\mathrm{kbp}$ fragment was amplified for both viruses. The PCR products were cloned in the Bluescript plasmid and the sequence was determined for the $5^{\prime}$ terminal region of the coat protein gene of SPLV$\mathrm{CH}$ (Fig. 3; nucleotides 1-423) and -T (Fig. 3, nucleotides $1-426$ ) and for part of the $3^{\prime}$ terminal region of the NIb gene of both viruses.

RACE (Rapid Amplification of cDNA Ends) method (Frohman, 1990) was used to amplify a cDNA fragment corresponding to the $3^{\prime}$ terminal region of SPLV-CH and -T genome. The RACE protocol allows the $3^{\prime}$ and $5^{\prime}$ ends of a cDNA to be amplified if a short stretch of sequence located between the ends is known. RNA was reverse transcribed using a primer that contains an 
Table 1

Pairwise percent amino acid sequence identities between the complete coat protein of SPLV-CH and -T and those of SPFMV, SPVG and other potyviruses

\begin{tabular}{llllllll}
\hline & SPLV-T & SPFMV & SPVG & PPV & PVY & TEV & TVMV \\
\hline SPLV-CH & \multirow{2}{*}{94.5} & 61.8 & 59.3 & 60.0 & 62.8 & 62.7 & 57.4 \\
SPLV-T & & 60.4 & 59.4 & 59.1 & 61.5 & 62.3 & 56.6 \\
SPFMV & & & 72.9 & 30.7 & 58.7 & 61.1 & 55.6 \\
SPVG & & & 56.5 & 56.6 & 65.0 & 55.5 \\
PPV & & & & 62.6 & 64.3 & 55.5 \\
PVY & & & & & 66.4 & 54.9 \\
TEV & & & & & & & \\
TVMV & & & & & & & \\
\hline
\end{tabular}

oligo(dT) sequence (17 residues) linked to an adapter sequence (17 residues). Amplification was subsequently performed using the adapter primer, which binds to each cDNA at its $3^{\prime}$ end and specific primers designed from the known sequence of the $5^{\prime}$ terminal part of the coat protein gene of the viruses (Fig. 1). The SPLV-CH and -T amplified fragments of approximately $750 \mathrm{bp}$ were cloned in the pCR-Script SK $(+)$ (Stratagene) and $\mathrm{pCR}^{\mathrm{TM}}$ II plasmids (InVitroGen), respectively.

\subsection{Sequence analysis of SPLV-CH and -T PCR products}

The partial deduced amino acid sequences of the C-terminal part of the NIb of SPLV-CH and - $T$ were aligned with the corresponding regions of SPFMV, SPVG, PPV, PVY, TEV and TVMV (Fig. 2). The alignment revealed the presence in the deduced amino acid sequences of SPLV-CH and $-\mathrm{T}$ (positions 60-70; Fig. 2) of the consensus motif (S,T)G-3X-T-3X-N(S,T) involved in the putative RNA polymerase function of potyviruses (Allison et al., 1986; Domier et al., 1987; Koonin, 1991; Poch et al., 1989).

Sequences of the SPLV-CH and -T coat protein gene and $3^{\prime}$ untranslated region are presented in Fig. 3. By analogy to the proteinase cleavage sites of potyviruses, the putative hydrolytic cleavage site $\mathrm{VHHQ} / \mathrm{A}$ between $\mathrm{NIb}$ and the coat protein was predicted for SPLV-CH and -T (Fig. 3). The sequences of the $3^{\prime}$ terminal part of SPLV-CH and $-\mathrm{T}$ genome include an ORF coding for the viral coat protein of 292 and 293 amino acids, respectively, followed by a $3^{\prime}$ untranslated region of 197 nucleotides (Fig. 3). The SPLV-T coat protein shared 93.4 and $94.5 \%$ identity, at the nucleotide and amino acid level respectively, with the corresponding sequence of the $1.30 \mathrm{kbp}$ fragment amplified from the potyvirus identified in sweetpotato clone GN1 and referred to as SPLV$\mathrm{CH}$. The SPLV-CH sequence was one amino acid shorter than that of SPLV-T. This difference was due to a three base deletion in the $5^{\prime}$ terminus of the coat protein gene of SPLV-CH (Fig. 3). From the 17 amino acid differences observed between both viruses, 14 were located in the variable $\mathrm{N}$ terminal region of the coat protein. Among the observed sequence dissimilarities, a $\mathrm{T}$ was found instead of an A in the SPLV-T DAG box (Fig. 3). The $3^{\prime}$ non-coding region of both viruses contains the consensus sequences GAGG (position 10291032 and 1032-1035 in SPLV-CH and SPLV-T, respectively) and CCTC (position 1038-1041 and 1041-1044 in SPLV-CH and SPLV-T, respectively) separated by five nucleotides, which could form a stem-loop structure possibly having a role in replication (Bryan et al., 1992). Nucleotide sequence identity between SPLV-CH and $-\mathrm{T}$ in the $3^{\prime}$ non-coding region was $97.0 \%$.

\subsection{Sequence comparisons between both strains of SPLV and potyviruses}

The deduced SPLV-CH and -T coat protein amino acid sequences were aligned with the corresponding regions of SPFMV, SPVG and selected potyviruses (Fig. 4). Pairwise percent sequence 
Table 2

Pairwise percent amino acid sequence identities between the conserved coat protein core of SPLV-CH and -T and those of SPFMV, SPVG and other potyviruses

\begin{tabular}{llllllll}
\hline & SPLV-T & SPFMV & SPVG & PPV & PVY & TEV & TVMV \\
\hline SPLV-CH & \multirow{2}{*}{98.6} & 68.5 & 67.1 & 68.1 & 64.8 & 65.3 & 58.3 \\
SPLV-T & & 67.1 & 66.2 & 66.7 & 64.4 & 64.8 & 57.9 \\
SPFMV & & & 81.0 & 71.8 & 63.4 & 65.3 & 58.8 \\
SPVG & & & 73.2 & 64.8 & 71.4 & 59.7 \\
PPV & & & & 67.1 & 66.2 & 58.3 \\
PVY & & & & & 67.1 & 58.3 \\
TEV & & & & & & & \\
TVMV & & & & & & & \\
\hline
\end{tabular}

identities between the complete coat protein and the conserved coat protein core of both strains of SPLV and selected potyviruses are shown in Tables 1 and 2. The SPLV-CH and -T coat protein and coat protein core sequence identities with selected potyviruses was less than 65 and $70 \%$, respectively. The sequence identity between both strains of SPLV and other potyviruses in the $3^{\prime}$ untranslated region was less than 55\% (Table 3). A search of the Genbank and EMBL databases showed similar identity levels with all previously sequenced potyviruses. Dendrograms of sequence relationship generated from the alignment of the complete coat protein, the conserved coat protein core and the $3^{\prime}$ untranslated region are shown in Fig. 5.

\section{Discussion}

Sweetpotato latent virus has been listed as a possible member of the family Potyviridae on the basis of morphological and serological data (Hammond et al., 1992; Moyer and Salazar, 1989). The use of potyvirus-specific primers (Colinet and Kummert, 1993) and subsequent application of the $3^{\prime}$ RACE procedure led to the cloning of the $3^{\prime}$ terminal part of the genome of SPLV-T and the SPLV-like virus from China. Our sequence analysis revealed consensus motifs and assigned unequivocally these strains as members of the genus Potyvirus. The consensus motif $(\mathrm{S}, \mathrm{T}) \mathrm{G}-3 \mathrm{X}-\mathrm{T}-3 \mathrm{X}-\mathrm{N}(\mathrm{S}, \mathrm{T})$ involved in the putative RNA polymerase function of potyviruses (Allison et al., 1986; Domier et al., 1987; Koonin, 1991; Poch et al., 1989) was found in the presumptive $\mathrm{NIb}$ of SPLV-CH and -T. Comparison of the determined and predicted cleavage sites in the $\mathrm{C}$-terminal regions of the potyvirus polyproteins revealed that they were usually cleaved at $\mathrm{Q} / \mathrm{A}$, $\mathrm{Q} / \mathrm{G}, \mathrm{Q} / \mathrm{S}, \mathrm{Q} / \mathrm{T}, \mathrm{Q} / \mathrm{V}$ or $\mathrm{Q} / \mathrm{E}$ dipeptide sequences by the nuclear inclusion a proteinase (NIa-Pro) and that $\mathrm{V}$ was usually found at position -4 of the cleavage sites (Shukla et al., 1994). The proposed cleavage site VHHQ/A between the NIb and the coat protein is similar to that recognized by the NIa proteinase of potyviruses (Shukla et al., 1994).

From the sequence analysis of the coat protein of SPLV-CH, a DAG triplet essential for aphid transmissibility of potyviruses (Atreya et al., 1990, 1991, 1995) was found in the expected position. The lack of aphid transmissibility of SPLV-T (Moyer and Salazar, 1989) could be explained by a mutation of an $\mathrm{A}$ to a $\mathrm{T}$ in its DAG box, as shown for TVMV (Atreya et al., 1991) and zucchini yellow mosaic virus (Gal-On et al., 1992). The isolation and purification of SPLV-CH should allow aphid transmission assays to be performed on the isolate originating from China to evaluate this hypothesis. Moreover, the generation of full-length cDNA clones from which infectious transcripts can be obtained should enable mutational analyses to study the involvement of such a mutation in the loss of aphid transmissibility of SPLV-T. The perpetuation of such an isolate without vectored transmission is not surprising since sweetpotato is vegetatively propa- 
Table 3

Pairwise percent amino acid sequence identities between the $3^{\prime}$ untranslated region of SPLV-CH and -T and those of SPFMV, SPVG and other potyviruses

\begin{tabular}{|c|c|c|c|c|c|c|c|}
\hline & SPLV-T & SPFMV & SPVG & PPV & PVY & TEV & TVMV \\
\hline SPLV-CH & 97.0 & 53.2 & 51.3 & 46.9 & 45.6 & 51.6 & 51.0 \\
\hline SPLV-T & & 53.7 & 50.8 & 46.9 & 46.7 & 51.6 & 53.1 \\
\hline SPFMV & & & 77.2 & 39.9 & 45.9 & 56.0 & 48.4 \\
\hline SPVG & & & & 37.9 & 39.0 & 56.1 & 42.4 \\
\hline PPV & & & & & 59.5 & 40.9 & 38.6 \\
\hline PVY & & & & & & 40.5 & 40.6 \\
\hline TEV & & & & & & & 45.4 \\
\hline TVMV & & & & & & & \\
\hline
\end{tabular}

gated and symptoms of virus infection are far from being obvious. As the occurrence of mixed infections is frequent in sweetpotato, heteroencapsidation of the SPLV-T RNA within a capsid consisting of the homologous coat protein and a

A

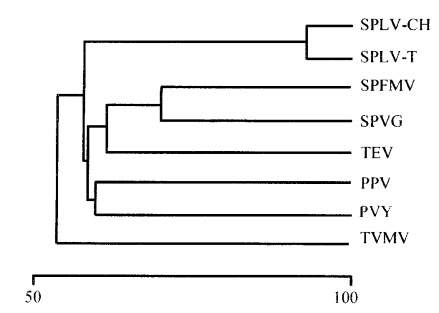

B
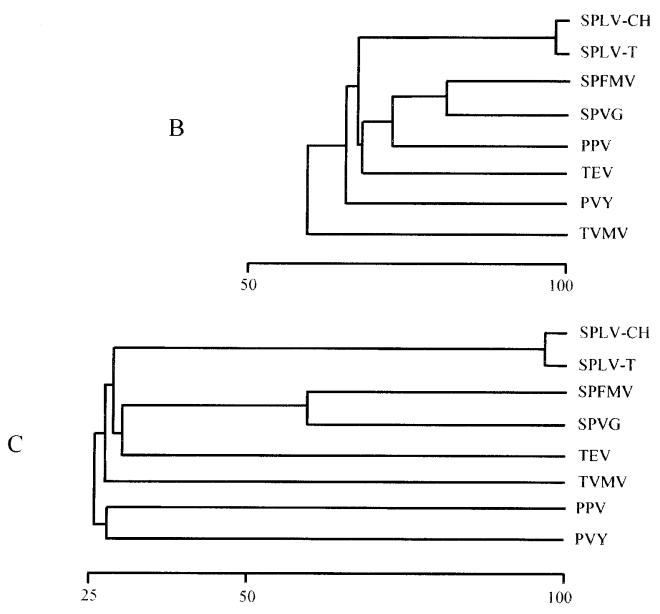

Fig. 5. Taxonomic relationship between the complete coat protein (A), the conserved coat protein core (B) and the $3^{\prime}$ non-coding region (C) of SPLV-CH and -T and those of SPFMV, SPVG, PPV, PVY, TEV and TVMV. The sequence relationship dendrogram was produced using ClustalV. heterologous one might equally explain the maintenance of SPLV-T in the environment.

Molecular characterization of potyviruses has revealed previously unrecognized relationships and led to the resolution of the virus/strains status of a large number of viruses (reviewed in Shukla et al., 1994). Complete coat protein and conserved coat protein core have been extensively used to identify and differentiate distinct potyviruses from their strains and to establish phylogenetic relationships of genera, viruses and strains within the family Potyviridae, assuming a constant rate of change for the coat protein (Rybicki and Shukla, 1992; Shukla et al., 1994). Extensive comparisons between the coat protein core of many members of the family Potyviridae revealed four levels of sequence identity (Shukla et al., 1994). The lowest level of sequence identity (15-35\%) corresponds to genera while the second $(55-75 \%)$ corresponds to distinct potyviruses and the third (74-88\%) reflects a closer evolutionary relationship between some distinct potyviruses still not as related as strains (fourth level, 90-99\%). Similarly, strains of the same virus share $83-99 \%$ nucleotide sequence identity in the $3^{\prime}$ untranslated region, while distinct viruses share generally less than $60 \%$ identity (Frenkel et al., 1989).

Based on the degree of coat protein sequence identity between SPLV-CH and -T (94.5\%), both isolates can be considered to be strains of the same virus. Sequence comparisons also indicated that SPLV is distinct from all the previously sequenced potyviruses since the identities were lower than $70 \%$ for the coat protein core. The $3^{\prime}$ 
untranslated region sequence comparisons also supported the assertion that SPLV-CH and -T are strains of a distinct member of the genus $\mathrm{Po}$ tyvirus. The dendrograms of sequence relationship generated from the alignment of the complete coat protein, the coat protein core and the $3^{\prime}$ untranslated region constitute valuable tools for the rapid assessment of the distinct/closely related/strain status of a newly-sequenced potyvirus such as SPLV. Such phylogenetic analyses clearly indicate that SPLV is neither related to SPFMV and SPVG, nor to any other virus, on an evolutionary basis, whereas SPFMV and SPVG are closely related reflecting a more recent evolutionary relationship.

\section{Acknowledgements}

This work was financially supported by EEC (Project STD3 TS3-CT910013).

\section{References}

Abad, J.A., Conkling, M.A. and Moyer, J.W. (1992) Comparison of the capsid protein cistron from serologically distinct strains of sweetpotato feathery mottle virus (SPFMV). Arch. Virol. 126, 147-157.

Allison, R., Johnston, R.E. and Dougherty, W.G. (1986) The nucleotide sequence of the coding region of tobacco etch virus genomic RNA: evidence for the synthesis of a single polyprotein. Virology 154, 9-20.

Atreya, C.D., Raccah, B. and Pirone, T.P. (1990) A point mutation in the coat protein abolishes aphid transmissibility of a potyvirus. Virology 178, 161-165.

Atreya, C.D., Atreya, P.L., Thornbury, D.W. and Pirone, T.P. (1992) Site-directed mutations in the potyvirus HC-Pro gene affect helper component activity, virus accumulation, and symptom expression in infected tobacco plants. Virology 191, 106-111.

Atreya, P.L., Lopez-Moya, J.J., Chu, M., Atreya, C.D. and Pirone, T.P. (1995) Mutational analysis of the coat protein $\mathrm{N}$-terminal amino acids involved in potyvirus transmission by aphids. J. Gen. Virol. 76, 265-270.

Barnett, O.W., Adam, G., Brunt, A.A., Dijkstra, J., Dougherty, W.G., Edwardson, J.R., Goldbach, R., Hammond, J., Hill, J.H., Jordan, R.L., Kashiwazaki, S., Lommel, S.A., Makkouk, K., Morales, F.J., Ohki, S.T., Purcifull, D., Shikata, E., Shukla, D.D., Uyeda, I. (1995) Family Potyviridae. In: F.A. Murphy, C.M. Fauquet, D.H.L.. Bishop, S.A. Ghabrial, A.W. Jarvis, G.P. Martelli,
M.A. Mayo and M.D. Summers (Eds), Virus Taxonomy. Springer, New York (Arch. Virol. (Suppl. 10)), pp. $348-$ 358.

Brunt, A.A. (1992) The general properties of potyviruses. In: O.W. Barnett (Ed) Potyvirus Taxonomy. Springer, New York (Arch. Virol. (Suppl. 5)), pp. 3-16.

Bryan, G.T., Gardner, R.C., Forster, R.L.S. (1992) Nucleotide sequence of the coat protein gene of a strain of clover yellow vein virus from New Zealand: conservation of a stem-loop structure in the $3^{\prime}$ region of potyviruses. Arch. Virol. 124, 133-146.

Chirgwin, J., Przybyla, A., MacDonald, R. and Rutter, W. (1979) Isolation of biologically active ribonucleic acid from sources enriched in ribonuclease. Biochemistry 18, 52945299.

Clark, C.A. and Moyer, J.W. (1988) Compendium of Sweetpotato Diseases. APS Press, The American Phytopathological Society, USA.

Colinet, D. and Kummert, J. (1993) Identification of a sweetpotato feathery mottle virus isolate from China (SPFMV$\mathrm{CH})$ by the polymerase chain reaction with degenerate primers. J. Virol. Methods 45, 149-159.

Colinet, D., Kummert, J., Lepoivre, P. and Semal, J. (1994a) Identification of distinct potyviruses in mixedly-infected sweetpotato by the polymerase chain reaction with degenerate primers. Phytopathology 84, 65-69.

Colinet, D., Kummert, J. and Lepoivre, P. (1994b) The complete nucleotide sequences of the coat protein cistron and the $3^{\prime}$ non-coding region of a newly-identified potyvirus infecting sweetpotato, as compared to those of sweetpotato feathery mottle virus. Arch. Virol. 139, 327-336.

Devereux, J., Haeberli, P. and Smithies, O. (1984) A comprehensive set of sequence analysis programs for the VAX. Nucleic Acids Res. 12, 387-395.

Domier, L.L., Franklin, K.M., Shahabuddin, M., Hellmann, G.M., Overmeyer, J.M., Hiremath, S.T., Siaw, M.F.E., Lomonossoff, G.P., Shaw, J.G. and Rhoads, R.E. (1986) The nucleotide sequence of tobacco vein mottling virus RNA. Nucleic Acids Res. 14, 5417-5430.

Domier, L.L., Shaw, J.G. and Rhoads, R.E. (1987) Potyviral proteins share amino acid sequence homology with picorna-, como-, and caulimoviral proteins. Virology 158, 20-27.

Frenkel, M.J., Ward, C.W. and Shukla, D.D. (1989) The use of $3^{\prime}$ non-coding nucleotide sequences in the taxonomy of potyviruses: application to watermelon mosaic virus 2 and soybean mosaic virus-N. J. Gen. Virol. 70, 2775-2783.

Frohman, M.A. (1990) RACE: Rapid amplification of cDNA ends. In: M.A. Innis, D.H. Gelfand, J.J. Sninsky and T.J. White (Eds), PCR Protocols: A Guide to Methods and Applications. Academic Press, San Diego, pp. 28-38.

Gal-On, A., Antignus, Y., Rosner, A. and Raccah, B. (1992) A zucchini yellow mosaic virus coat protein gene mutation restores aphid transmissibility but has no effect on multiplication. J. Gen. Virol. 73, 2183-2187.

Hammond, J., Jordan, R.L., Larsen, R.C. and Moyer, J.W. (1992) Use of polyclonal antisera and monoclonal antibod- 
ies to examine serological relationships among three filamentous viruses of sweet potato. Phytopathology 82, 713-717.

Higgins, D., Bleasly, A. and Fuchs, R. (1991) ClustalV: improved software for multiple sequence alignments. CABIOS 8, 189-191.

Koonin, E.V. (1991) The phylogeny of RNA-dependent RNA polymerases of positive-strand RNA viruses. J. Gen. Virol. 72, 2197-2206.

Lain, S., Riechmann, J.L. and Garcia, J.A. (1989) The complete nucleotide sequence of plum pox potyvirus RNA. Virus Res. 13, 157-172.

Moyer, J.W. and Salazar, L.F. (1989) Virus and virus-like diseases of sweet potato. Plant Dis. 73, 451-455.

Poch, O., Sauvaget, I., Delarue, M. and Tordo, N. (1989) Identification of four conserved motifs among the RNAdependent polymerase encoding elements. EMBO J. 8, 3687-3874.

Robaglia, C., Durand-Tardif, M., Tronchet, M., Boudazin, G., Astier-Manifacier, S., Casse-Delbart, F. (1989) Nucleotide sequence of potato virus ( $\mathrm{N}$ strain) genomic RNA. J. Gen. Virol. 70, 935-947.
Rybicki, E.P. and Shukla, D.D. (1992) Coat protein phylogeny and systematics of potyviruses. In: O.W. Barnett (Ed), Potyvirus Taxonomy. Springer, New York (Arch. Virol. (Suppl. 5)), pp. 139-170.

Shukla, D.D. and Ward, C.W. (1989) Identification and classification of potyviruses on the basis of coat protein sequence data and serology. Arch. Virol. 106, 171-200.

Shukla, D.D., Lauricella, R. and Ward, C.W. (1992) Serology of potyviruses: Current problems and some solutions. In: O.W. Barnett (Ed), Potyvirus Taxonomy. Springer, New York (Arch. Virol. (Suppl. 5)), pp. 57-69.

Shukla, D.D., Ward, C.W. and Brunt, A.A. (1994) The Potyviridae. CAB International, Wallingford.

Ward, C.W. and Shukla, D.D. (1991) Taxonomy of potyviruses: Current problems and some solutions. Intervirology 32, 269-296.

Ward, C.W., McKern, N.M., Frenkel, M.J. and Shukla, D.D. (1992) Sequence data as the major criterion for potyvirus classification. In: O.W. Barnett (Ed) Potyvirus Taxonomy. Springer, New York (Arch. Virol. (Suppl. 5)), pp. $283-$ 297. 